\title{
Speculative Fiction for the Future of Man and Civilization
}

\author{
Bogdan Trocha \\ Doctor of Science (Philology), Professor, University of Zielona Góra (Zielona Góra, Poland) \\ E-mail: bwtrocha@gmail.com \\ https://orcid.org/0000-0003-2348-4813
}

\begin{abstract}
The main thesis of the article is the comparison of speculative fiction with the challenges facing modern man. Introductory questions are two issues. How can fantasy become the subject of cultural reflection on the future of human civilization? Can contemporary speculative fistion act as an instructional story about the unknown? The author indicates several basic models of using speculative fiction. However, it limits itself to creating an introductory canon, which is associated with literary speculations regarding the impact of man and technology on the future of civilization.

Keywords: myth, speculative fiction, political fiction, space opera, postapocalyptic fiction, ecological science fiction
\end{abstract}

Received: September 11, 2019; accepted: October 5, 2019

Future Human Image, Volume 12, 2019: 104-114.

https://doi.org/10.29202/fhi/12/9

\section{In the face of the unknown - in search of model stories: myth, fantasy, speculative fiction}

The notion of speculative fiction has been firmly established in popular culture for many years. However, while it is very easy to point to the essential features of the poetics of this type of novel, it is much more difficult to point to the cultural paradigm from which both speculative fiction and the need to use this type of poetics stems. The foundations of this type of cognitive and creative procedures should be found in two aspects of the human condition. The first one is certainly the aspiration to discover the sense of everything that man experiences in various ways in the world around him. This, of course, is connected not only with discovering the rationality of the universe, but above all with rationalizing individual elements of the world and the principles that make it up. The second aspect is connected with connecting the experience of mystery with the experience of a potential threat that may be hidden in it. Man seeking certainty tries not only to discover and rationalize the mechanisms of the surrounding universe, but also to go beyond time and space limitations in order to be sure of understanding the mechanisms of what is given, not only in common experience.

(C) Trocha, Bogdan, 2019 
The search for the meaning of things and rationalising the world brought its first effect in mythical narratives. In the consciousness of the primitive man, who in order to survive had to have the fullest possible knowledge about his environment, a process took place, as a result of which the rules governing this environment were rationalized in a way characteristic of mythical thinking. This mechanism was precisely described by Gerardus van der Leeuw [van der Leeuw, 1997:132-143]. The effect of this action is not a symbolic rationalization of the principles organizing the existence of the Living Space, but first of all the creation of a functional model of the whole reality, which in mythical rituals was subject to a specific taming. The importance of this functional model was so great for a mythical thinker that the myth became not only a story about the boundaries of reality and the norms that govern it, but even, as Mircea Eliade wrote, a model story [Eliade, 1993:412-414]. What is important for us is the mechanism of creating a model story. On the basis of data concerning the regularity in the changeability of the state of things in the surroundings, imaginary figures were created, which mediated hidden mechanisms and principles. Creating the first model of the universe required not only empirical experience, but also imagination, which allowed to give what was given in the experience meanings of power, will and finally name. This opened up the possibility to create myths as model stories about the beginnings.

The use of imagination in a necessary way leads us to the notion of fantasy. The concept itself has been characterized by different meanings through the years and epochs. In recent years, however, it has been synonymous with the creation of imagination. The question is whether this imagination is empty or contains some interesting cognitive quality. Aristotle assumed that this concept has several levels of meaning. Two of them are important for us. The first one is an image accompanied by an understanding of what is imagined. The second is an image of something based on sensual experience [Abramowiczówna, 1965]. Fantasy, in one of the meanings assigned to it, would combine the game of imagination with the experience of the world and rationalization of what has been created by imagination. Of course, fantasy is also an image based on visions of dreams or human desires.

Questions about the cognitive status of fantastic imagery appeared in Samuel Taylor Coleridge's [Coleridge, 2018] essays, in which he addressed the issue of imagination and fancy. Fantasy, in his opinion, as an ability worse than imagination can only serve to organize the data present in the experience in a logical way, but not subject to synthesis. However, imagination allows us to understand the world around us. And the artist's imagination can not only be used to understand the world around him, but can also lead, based on data from the original imagination, to the creation of a vision of new worlds. A completely different concept of fantasy was created by Roger Caillois [Caillois, 1965], in which he saw the essential function of fantasy in its negative aspect of action in relation to reason. The content of fantasy was supposed to raise questions in people and lead to the problematization of the rational image of the world. This model of fantasy becomes particularly important after the Enlightenment, when the belief in the power of reason and technology led to tendencies creating a new type of industrial utopia.

The element that crowns these discussions on fantasy is the emergence of specualtive fiction, the most general feature of which is the assumption that we are dealing with a literary fiction using the motif: "what if?" Basically, the introduction to this concept is attributed to Robert Heinlein [Heinlein, 1947]. The essence of speculative fiction in his understanding was to create new boundary conditions that do not exist in reality and to introduce into the environment that will be affected by it a human being in order to literary test his potential 
reactions. Thus understood, speculative fiction may have several basic literary realizations. Each time, however, the dominant anthropological perspective that will be present in them will be important. Like Colerigde's myth or imagination, it may lead not only to the creation of new models of reality, but also to testing their consequences in a literary laboratory. This is all the more important because the faith in industrial utopias has passed away and the pace of civilization changes and potential threats connected with them is increasing. Thus, speculative fiction can become a plane on which the predicted future states of things are tested for rationalization and evaluation. By creating potential worlds, fiction opens up a literary opportunity to test their consequences before they appear. In this sense, speculative fiction has features in common with Coledrige's imagination through the possibility of creating worlds that do not yet exist. Caillois' concept is linked to the destruction of faith in the unchangeability of the present world and its rational interpretation.

Thus, literature using fantastic imagery can use imagery for purely aesthetic purposes. It can also use them to speculate about the future of man, civilization and the world in general. Finally, it can also combine imaginative elements with religious symbols, referring to the spiritual condition of contemporary man.

\section{Man and his condition}

There is no doubt that the understanding of the human condition has its cultural roots. The problem is that in postmodern times the main cultural narratives were suspended. If we add to this the consequences of globalization, progressive secularization in Western civilization and the influence of new technologies on man, it will turn out that the question about the human condition becomes an open question. Requiring not only the determination of potential threats, but also the description of man beyond the categories related to the sacred.

The first speculative literary attempts connected with the human condition refer to human limitations and their possible transgression. In this case, several fundamental issues can be pointed out. The first one is connected with knowledge, or rather with potential omniscience and possible consequences of such a state of affairs. An interesting attempt is made in Robert Silverberg's novel The Stochastic Man [Silverberg, 2014], in which this problem is apparently solved. People forecasting the future are able to create reality. However, the fact of having such skills does not allow for full knowledge, but rather for speculation in the field of increased probability. Silverberg's novels address several issues of human limitation, such as mortality, limited cognition, cultural forgetting and, above all, anthropocentrism. The solutions we find in his novels only seemingly show the subjective models in which these boundaries have been crossed. In reality, applying the principle of problematicality of science, he indicates that complications resulting from new qualities inscribed in the human condition. Omniscience turns out to be apparent, the price for immortality is connected with the death of other people. In the case of cultural memory, however, it rather describes what is lost value [Silverberg, 1999]. The phenomenon inscribed in the human condition is the uniqueness of the experience of the world funded by the individuality of man himself. Thus, the limitation, if properly presented, becomes an asset. The only technical issue is to create fantastic artifacts that allow one to experience the full experience of the other person within the framework of a modified secondary experience. Silverberg defines the importance of the problem of human cognition, pointing to its three fundamental spaces: cognition of the other, cognition of the future and breaking cultural forgetting. At the same time, however, he points to the possibility of overcoming 
these limitations and the consequences of these actions. Full cognition, as he understands it, is cognition that assumes, first of all, awareness of one's own limitations. And among them, anthropocentrism seems to be the most important. Its cultural consequences can be seen in the novel Downward to the Earth [Silverberg, 1970], where the most important limitation of human cognition is the assumption of human superiority. This leads to the reduction of other conscious subjects, but above all to the realization of the reduction of the image of the world in which man lives. The theme of anthropocentrism introduces two fundamental issues. The first is related to the place and role of man in the universe, and the second is related to the question of the certainty of our cognition.

The problem of anthropocentrism in novels of the speculative fiction type not only polemicizes with religious stories about the origin of man, but above all creates potential models of subjects thinking abstractly and ordering their relations with others in the field of ethics. Such an approach opens not only the question of the problematic superiority of man over other living beings in the Cosmos, but also raises the extremely important issue of subjective images of the world. Philip K. Dick addressed the issue of human cognition in his novels. Pointing to the fundamental question of whether the world we know is what it is in reality or whether it is the result of our capabilities and limitations, and thus in some sense only a human projection of the real world. This problem, like anthropocentrism, has its own two literary realisations. The first one is connected with the mechanism of excluding non-human subjects from the world of the human environment. The second is a consequence of the first and condemns man to life in a world that is only a human vision of this world.

Trying to overcome these limitations brings a whole range of ideas and problems. One of the models of crossing the limits of human condition is transforming human subjectivity. The search for full omniscience leads to the loss of human subjectivity. In Frank Herbert's Dune [Herbert, 1980], the way to gain full knowledge about the universe was to be a genetic breeding project. However, it is the total biological transformation of the protagonist that leads to the price of crossing the boundaries of human cognition. Entering a new area of quality is often connected with the loss of the existing form of subjectivity. Immortality based on cloning excludes the consciousness of the previous existence. The first literary speculations that attempt to transcend human limitations, based on the strengthening of human intellectual potency or the use of robots or genetic technology, have rather the aspect of introducing the problem of human condition in the literature of speculative fiction. They are based on mechanisms designed to articulate the problem and point to various aspects of its approach. One of the most important aspects of early speculative fiction is the issue of depersonification. Man is reduced to an economically valorized element of the global system. The most important thing, however, is that in describing such phenomena, writers have defined the framework boundaries of human subjectivity. They include the right to freedom, self-determination and the right to truth. All the fantastic dystopias, starting with the novels of George Orwell and Aldous Huxley, raise this theme. The systemic borderline of human beings leads necessarily to speculation about their social and subjective consequences. The limitation of human rights can be the beginning of the changes in the human biological code, as Herbert George Wells predicted in The Time Machine [Wells, 2001]. Consequently, speculative fiction addresses the issue of the evolutionary regression of man and his return to the primordial forms of existence [Aldiss, 1958]. Asking about the crossing of the boundaries of human condition, the writers pointed not only to the processes of technological or genetic evolution, but also to the processes of degradation. Thus determining both the human condition and the place of man in the Cosmos. 
However, the younger generation of writers is much more creative in their approach to these issues. Among the new novels, the most common problems are posthumanism and the concepts of human subjectivity that arise on the basis of the latest trends. The first of the important motifs is the technical aspect of separating consciousness from the body. The effects of speculation on this problem are very interesting. They may lead to a technological formula of immortality, then consciousness will be introduced to virtual reality [Hamilton, 2007-2010]. Another idea is related to the technological generation of secondary consciousness resulting from the introduction into the brain of personal control programs based on digital copying of human consciousness [Hamilton, 2015]. The consequence of such a procedure is multiple. Firstly, several personality models may appear in the field of human consciousness. Secondly, the abuse of such technology leads to a change in human relationships, which are more based on interactions with virtual personalities than with their subjective carrier. The most interesting consequences combine into both motifs the transfer of human consciousness outside the body with the motif of cloning [Morgan, 2002-2005]. The result is a super elite whose members are people living for hundreds of years in bodies cloned from their own cells. This leads to completely new relationships in the mechanisms of institution management. A side effect is the trade in bodies, treated as carriers for consciousness and an interesting penitentiary model, in which only consciousness is subject to orders. Separating consciousness from the body often leads to a situation in which consciousness can be embedded in many bodies at the same time. The only problem is to what extent this consciousness is modified. In Ann Leckie's novels Ancillary Justice [Leckie: 2013] we deal with the situation of technical reduction of human consciousness in order to create a multiplied soldier having one decision centre but many bodies. This not only cripples the human being, but also deprives him of his humanity. Another variant of a similar procedure can be seen in Linda Nagata's novels The Red Trilogy [Nagata, 2013-2015] in which nanotechnology allows for a significant change in the work of the human brain, creating an optimal soldier who, exceeding his biological limitations, also loses a part of his own humanity.

The theme of technological improvement of human condition is one of the most explored topics by speculative fiction. Authors usually use a few basic thematic schemes. In the first one, technological interference in human bodies allows for its complete reconstruction, which introduces another aspect of specifically understood immortality. Based on a biotechnological reconstruction of a practically dead human being [McDonald, 2010]. Often this motif is combined with advanced human cyborgization, which results in McDonald's creation of a vision of man being the owner of technological avatars. The second scheme is based on the technological strengthening of the natural capacity of the human body, which leads to the creation of completely new possibilities of effective human action [Morgan, 2002-2005]. However, the most interesting procedure appears in Dick's novels, where the technological advancement associated with cyborgs and androids is so complicated that man, in order to have a guarantee that he is human, must carry out complicated tests [Dick, 1996]. Literary explorations of this problem lead not only to the discovery of potential mechanisms of postmunicipal models of the future human being, but also raise the problem of the consequences of these procedures. Most often connected with the loss of an individual identity inscribed in our biology. Borderline images can be seen in the novels by Lavie Tindhar [Tindhar, 2016], where cyborgization has been carried out so far that there are robots that have only a deep memory of their human origins. Man can live as a hybrid of a human organism supported by implants of extra-human life forms. The darkest vision, however, is to fabricate children, 
created from DNA collected from the environment and not from human parents. Children spend this prenatal period in machines.

Thus, one of the most important motifs for the speculative fiction of the future of the human condition is to set it in two perspectives. The first one is connected with interference in the human organism at the level of biotechnology, which will result in hybrid beings, as can be seen in The Drowned Cities [Bacigalupi, 2014 ]. A hybrid is not only a creature that biologically combines the characteristics of various animals, but is also a creature that is aware of its hybridity. This causes not only bioethical but also cognitive problems. The second perspective is related to the technological interference in the human organism. The result of this can be the complete robotisation of the human spawn. It can also be the embedding of the modified human consciousness in a mechanical body, as is the case with The Windup Girl [Bacigalupi, 2009]. The final effect is the creation of a cyborg that cannot exist without technological support. As we can see, posthumniastic and transhuman visions of the future of man have both positive and negative aspects.

However, there is also another fundamental problem related to the technological advancement of identity programs used in androids. Building these programs in such a way that androids can enter into communication interactions with humans has led to the creation of not only an advanced AI, but also, and above all, an AI asking existential questions within the framework of its activity in human spaces, or completely excluding them. In both cases, however, there will be two very interesting effects of the coexistence of biological man and AI.

\section{Societies of the future}

Among the classic novels on the societies of the future, models based on utopia and dystopia figures should be pointed out. The first one, still associated with an optimistic approach to the evolution of a society stimulated by both new technologies and political ideas, is most often associated with fantasy burdened with ideological ballast. A classic example of such a vision of society are novels like Aelita Aleksei Tolstoy's [Tolstoy,1956] or Mgławica Andromedy Ivan Jefremov's [Jefremov, 2015], which are classic communist utopias in which the state raises children, cares for families, nobody works, and there are no social inequalities. And poverty and hunger have been eradicated in it. However, most writers tend to address the problem of the price society pays for the utopian state model. In these cases, writers usually raise the issue of introducing a privileged social group living at the expense of the slave labour of the rest of society, as is the case in the novels by Wells The Time Machine or Rafał Kosik's Różaniec [Kosik, 2017]. An important issue remains the problem of the mechanism for managing such a society. Most often it is based on the permanent surveillance of Mord załozycielski [Wnuk-Lipiński, 1989], the total atomization of the members of the $451^{\circ} \mathrm{Fahrenheit}$ society [Bradbury, 2008] and, most importantly, on the institutionalized terror of the group exercising the authority of Wybrakówka [Divov, 2005]. Most often, the essence of such a society remains a fundamental lie and results not only in a struggle to reach the truth, as is the case in the novel Cała prawda o planeciet Ksi [Zajdel, 2008]. Another aspect of such speculative models is the side effects that society pays for living a secure and just system. This may be a mechanism based on total transparency of human thoughts and intentions, which not only excludes the planning of crimes, but also implies the possibility of altering the human consciousness of the criminal in such a way as to create a new personality by destroying an old one, which is what happens in the novel The Demolished Man [Bester, 1953]. Another result is the creation of places of 
isolation, which are intended to serve the policy of rehabilitation of criminals, and ultimately become a tool for the elimination of political opponents through the manipulation of the law, as happened on The Status Civilization [Sheckley, 2015]. The common feature of these models is the indication of the possibility of degradation of the society of the future. The mechanism of degradation is most radically presented in novels taking up postapocalyptic motifs. The reasons for the end of civilization may be different, but the consequences are usually of a similar nature. In older novels, this may be related to cultural regression, as was the case in the novel Non-stop [Aldiss. 1958], or even to the total reduction of man to the level of a productive animal for the benefit of primates, as seen on The Planet of Apes. Another mechanism for the degradation of human society is linked to the consequences of nuclear conflicts. The result of this may be not only global pollution of the environment, but also the destruction of the economic foundations of civilisation. As a result, man not only returns to primitive forms of farming, but in the worst cases, radioactive contamination itself dies as a species. Most postapocalyptic novels connected with technical or biological cataclysms indicate not only the possibility, often as banal as human error, of bringing such a cataclysm into the modern world. Above all, it points to the fragility of not only human existence in the face of global cataclysms, but even entire civilizations. The mildest effect of such a potential cataclysm is the phenomenon of renewed barbarity of culture. Interesting not only because he speculates on the mechanisms governing the degradation of civilization and culture, but also because he raises the issues of the consequences of such mechanisms. All these models, however, have several common features. The first is the violent and most often globally unintended attitude of the human society towards the necessity of radical and tragic changes in the environment and culture. The second one is based on the creation of model models of civilization reduction connected with breaking the continuity of cultural memory and the disappearance of basic types of previously accepted models of behaviour.

Another model of society subject to speculative manipulation is connected with societies based on authoritarian or even totalitarian mechanisms. We have several types of authoritarianism in this category. The first is connected with politically privileged power groups, as is the case in the novel Wyjście z cienia [Zajdel, 1990]. Most often it is shown in the field of political efforts to maintain the political status quo or, on the contrary, in the field of efforts to gain knowledge of the authorities about the truth about the political system. This mechanism is very often based on the principle of believing that the discovered and published truth about the true mechanisms of power should lead to a revolution in order to restore public order, as described in Mord założycielski. The next two models are based on mechanisms of authoritarian power, which originates from religion or business institutions. In the first case, as can be seen in the Dune cycle [Herbert,198-1981], religion can liberate not only long suppressed negative feelings, but can even lead to a sacred authoritarianism introducing its religious and cultural form of society through religious warfare. The most interesting form of authoritarianism seems to be the one based on the activities of corporations. This is not only because the most complicated supervisory mechanism appears there. A mechanism that involves manipulating both public opinion and official authorities. Based on economic power and total disrespect for morality, the authoritarian model is the most efficient, and the only form of salvation turns out to be an escape from its sphere of influence.

Literary speculation on societies that build a large part of their structures on advanced digital technology systems takes on a completely different form. They not only introduce a digital model of supervision over individual members of a given society, but also build them 
very often on the basis of entities deprived of their physical representation. Such models are the result of two types of procedures. The first one is connected with the posthumanistic concept of a human being starting to live as an element of a computer program. In this case, however, we are dealing with images in which such a procedure is so common that entire communities are created in virtual reality. An interesting aspect of this type of speculation is the assumption of such a scale of technological development that it begins to introduce a problem with a conscious and unambiguous distinction between physical reality and the virtual world. This leads to a situation in which a person potentially becomes not only an inhabitant of two different types of worlds, but first of all a member of two different types of societies, which is visible in the novel Central Station. Another source of this type of speculation has its origins in advanced video games. At the same time, the subjects of the game can be endowed with some form of consciousness (Demi-Mond. Winter) [Rees, 2018] or, what is much more interesting, they become subjects that can go beyond the virtual space and its motoric limitations. In both cases it is interesting to assume the virtual multiplication of the real world of human reality and by creating the possibility of a smooth interpenetration of these two aspects of the world to create a new, interesting model of social community. Unfortunately, one of the basic consequences of building such a model of the world and societies inscribed in its reality will be the issue of communication and individual identity of a human being. In the first case, there are literary projections in which the members of the community are technologically united in one consciousness managing all the bodies of the community (Głębia) [Podlewski, 20152018]. The second mechanism is related to the atomization of the individual in $\mathrm{s}$ The negative aspect of speculation on societies using the latest technologies is not to reduce man to a posthumanistic existence coexisting with hybrids and androids, but above all, it leads to several fearless models of future societies. The first one is based on the pursuit of profit. The second is focused on the consumption of goods produced by robotic systems. The third is based on a set of completely atomized units. The most disturbing, however, is the concept of such a farreaching robotization of our environment that man will not only cease to manage and repair it, but will even understand it. This means that future generations can become fully dependent on technical systems that they will not only not understand, but over which they will have no power or influence over the way they work. This model is complemented by the possibility of triggering a global conflict, the sole aim of which is to restore society to the future of the natural characteristics of modern man.uch a society, which is the price for the preservation of individuality and subjective freedom.

\section{Technology and consequences of its application}

The first, but extremely important aspect of speculative treatment of technology is exploration of the Cosmos. We have a lot of interesting literary projects connected with this motif. Starting from the model of using asteroids, planets and moons as sources of important elements. This, of course, raises the question of the technologies used for this purpose and the mechanisms of management. As far as technologies are concerned, most often they are automatons, robots or androids controlled by humans (I, Robot) [Asimov,1950]. Management takes various forms: monarchy (Dune) [Herbert, 1980], corporation (Takeshi Kovacs Lev) [Morgan, 2002-2005], religion (God the Emperor Dune) [Herbert, 1981], or military (Gtębia). The issue of the colonization of the Cosmos remains a very important issue. It is connected with cultural, anthropological and technological dimensions. The first two introduce a disturbing 
motif of a meeting with aliens. This motif has a few of its realisations. The first one is connected with the colonial attitude to the races standing on a lower civilization level (Downward to the Earth) [Silverberg, 1970]. The second one takes on the importance of problems with understanding potential cultural diversity and not always expected by people consequences of the meeting (The Sparrow) [Russel, 1996]. The third deals with the issue of flights so far away that they exclude not only the return to Earth, but also support in the colonization process (The Void Trilogy) [Hamilton, 2007-2010]. A completely new idea is the phenomenon of terrifying planets so as to generate on them an environment enabling human existence (The Expance) [Corey, 2011-2019]. The most fundamental issues of speculation around the exploration of the Cosmos, however, concern three issues: Aliens, the evolution of human civilization structures and the possibility of entering parallel worlds. The motif of the exploration of the Cosmos is often connected with speculations connected with visions of future armed conflicts taking place on a cosmic scale. It is here that both the issue of technology that can destroy not only the planet, but also burn galaxies (Gtębia) and the issue of new legal regulations for this type of conflicts (Starship Troopers) [Heinlein, 1987] appear. There are also speculations about the impact of these new war technologies on the human condition (The Forever War) [Haldeman, 2006], (Redshirts) [Scalzi, 2013].

The most disturbing and most frequently explored, however, are the issues related to the posthumanistic vision of the man of the future. This includes both the modification by aliens, who are no longer aliens, despite completely new possibilities (The Prefect) [Reynolds, 2007] and the degradation to the level of free beings (The Abyss Beyond Dream). Still another aspect brings problems connected with the hybridization of man (Zoo City) [Beukes, 2018] or even the creation of technocrats (Lágrimas en la lluvia) [Montero, 2016]. These speculations do not focus so much on the technological aspects of this type of treatments, but rather raise the issues of anthropological consequences. The paradigm of this type of motifs is certainly complemented by cyberpunk novels raising not only the issues of the influence of digital technologies on human existence (Sprawl Trilogy: Neuromancer, Count Zero, Mona Lisa Overdrive) [Gibson, 2017] and condition, but also not avoiding speculations related to the influence of psychoactive substances on man and society (Vurt) [Noon, 1995]. Speculations around man and human society bring not only images of the continuous conquest of the Cosmos. Often there are also visions showing the progressive degradation of society (Parrish Plessis Series) [de Pierres, 2004-2005] and predicting the end of the human species (Jak nie zginie ludzkość) [Zimniak, 2008]. A complete novelty of the recent years is the introduction of man in technology that allows manipulating reality on the quantum level with very interesting consequences that this creates for the man of the future (The Quantum Thief) [Rajaniemi, $2011]$.

The last, important issue raised by contemporary speculative fiction is the problem of destruction of the Earth's natural environment and the consequences of this phenomenon that may occur in the near future. Speculations related to this motif have several basic forms of storyline. The first one is related to the crisis caused by melting glaciers, which in consequence leads to the sinking of large areas of the Earth (The Drowned Cities). The second deals with the lack of fresh water ( The Water Knife) [Bacigalupi, 2015]. This is related not only to forcing people to look for ways to live in desert and semi-desert areas, but also to the taking over of natural fresh water sources by corporations. Water is becoming one of the most valuable goods of the Earth. Another model is related to the chemical contamination of the Earth's environment to the extent that the planet cannot cope with. As a consequence, toxic earth begins to give birth 
to toxic plants, and man does not have sources of healthy plant proteins. This is the price of both environmental pollution and unregulated interference in plant DNA. In this model of the world, pure DNA of utility plants becomes an extremely valuable commodity. Another model focuses on testing the effects of overpopulation of the world (Stand on Zanzibar) [Brunner, 1999]. At the same time, the consequences of taking over the duty to work by automats, controlling them by computers and reducing human existence to a struggle for power, global drug addiction and total focus on the carnival that human life has become. The latest model of ecological speculation is connected with showing the civilisational consequences of such a crisis for man. It no longer produces food on its own. It is also unable to use the technology of its own civilisation. In the automated world, man has culturally rejected science and cultural memory (Pump number six and other stories) [Bacigalupi, 2008]. When a cataclysm occurred, he remained completely helpless towards it (The Troika) [Chapman, 2012].

The question remains, what function do they play in the contemporary world of novels of the speculative fiction type. Are they, like myths, instructional stories on the path of civilization's expansion into the unknown? They certainly have something to do with myths. They often point to consequences of cosmic significance. And yet, unlike myths, they refer to the future. They do not design answers to questions about the borders of the Cosmos and the norms that govern it. They are more concerned with the problem of future potential consequences of specific human actions. It is surprising that very often these speculations are pessimistic. While myths brought patterns that had to be repeated in order to survive by repeating the actions of heroes and ancestors, speculative fiction novels rather bring images of actions that should not be taken in order to survive in the future. Thus, it can be said that speculative fiction has become a space for many writers to speculate on the potential effects of technological experiments, the directions of civilization evolution based on them, and the exploration of the Cosmos. Literature has become a platform on which the latest scientific projects are subject to speculation in a broader perspective than that offered by detailed sciences responsible for the contemporary, next technological revolution.

\section{[ㅁ] References}

Abramowiczówna, Zofia. Słownik grecko-polski. t. 1-4. PWN, 1965.

Aldiss, Brian. Non-Stop. Faber\&Faber, 1958.

Asimov, Isaac. I, Robot. Gnome Press, 1950.

Bacigalupi, Paolo. The Drowned Cities. Little, Brown Book Group, 2014.

Bacigalupi, Paolo. The Windup Girl. Little, Brown Book Group, 2009.

Bacigalupi, Paolo. The Water Knife. Knopf, 2015.

Bacigalupi, Paolo. Pump Six and Other Stories. Night Shade Books, 2008.

Bester, Alfred. The Demolished Man. Shasta Publishers, 1953.

Beukes Lauren. Zoo City. Penguin Books Ltd, 2018.

Bradbury, Ray. Fahrenheit 451. HarperVoyager, 2008.

Brunner, John. Stand on Zanzibar. Gollancz, 1999.

Caillois, Roger. Au coeur du fantastique. Éditions Gallimard, 1965.

Chapman, Stepan, The Troika. Ministry of Whimsy Press, 2012

Coleridge, Samuel, Taylor. Biographia Literaria; or Biographical Sketches of My Literary Life and Opinions. HardPress, 2018.

Corey, James, S.A. The Expance. Orbit Books, 2011-2019. 
Dick, Philip. K. Do Androids Dream of Electric Sheep. Del Rey, 1996.

Divov, Oleg. Wybrakówka. przeł. A. Sawicki. Solaris, 2005.

Eliade, Mircea. Traktat o historii religii. Przeł. J. Wierusz-Kowalski. OPUS, 1993.

Gibson, William. Sprawl Trilogy: Neuromancer, Count Zero, Mona Lisa Overdrive. Gollancz, 2017.

Haldeman, Joe. The Forever War. Thomas Dunne Books, 2006.

Hamilton, Peter. F. The Void Trilogy. PanMacmillan, 2007-2010.

Hamilton, Peter, F. The Abyss Beyond Dream. Del Rey Books, 2015.

Heinlein, Robert. On the Writing of Speculative Fiction. Of Worlds Beyond: The Science of Science Fiction Writing. Ed. By Lloyd Arthur Eshbach. Fantasy Press, 1947.

Heinlein, Robert. Starship Troopers. Ace, 1987.

Herbert, Frank. Dune, Hodder\&Stoughton. 1980.

Herbert, Frank. God Emperor of Dune. Putnam, 1981.

Jefremow, Iwan. Mgławica Andromedy. przeł. L. Kaltenbergh. Solaris, 2015.

Kosik, Rafał. Różaniec. Powegraph, 2017.

Leckie, Ann. Ancillary Justice. Orbit Books, 2013.

Leeuw van der, Gerardus. Fenomenologia religii. przeł. J. Prokopiuk. Książka i Wiedza, 1997.

McDonald, Ian. The Dervish House. Pyr, 2010.

Montero, Rosa. Lágrimas en la lluvia. Booket, 2016.

Morgan, Richard. Takeshi Kovacs Lev. Victor Gollancz Ltd, 2002-2005.

Nagata, Linda. The Red Trilogy. Simon \& Shuster, 2013-2015.

Noon, Jeff, Vurt. St. Martin's Griffin, 1995.

Pierres de, Marianne. Parrish Plessis Series. Orbit Books, 2004-2005.

Podlewski, Marcin. Głębia, t. 1-4. Fabryka Słów, 2015-2018.

Rajaniemi, Hannu. The Quantum Thief. Gollancz, 2011.

Rees, Rod. Demi-Monde: Winter. William Morrow, 2011.

Reynolds, Alastair. The Prefect. Gollancz, 2007.

Russel, Mary, Doria. The Sparrow. Villard, 1996.

Scalzi, John. Redshirts. Gollancz, 2013.

Sheckley, Robert. The Status Civilization. Open Road Integrated Media, 2015.

Silverberg, Robert. The Stochastic Man. Open Road Media Sci-Fi \& Fantasy, 2014.

Silverberg, Robert. Lord Valentine's Castel. Voyager, 1999.

Silverberg, Robert. Downward to the Earth. Doubleday, 1970.

Tindhar, Lavie. Central Station. PS Publishing, 2016.

Tołstoj, Aleksy. Aelita. przeł. Alicja Sternowa, Iskry, 1956.

Wells, Herbert, George. The Time Machine. Pearson Education Limited, 2001.

Wnuk-Lipiński, Edmund. Mord założycielski. Iskry, 1989.

Zajdel, Janusz. Cała prawda o planecie Ksi. Wydawnictwo Literackie, 1983.

Zajdel, Janusz. Wyjście z cienia. Wydawnictwo Literackie, 1990.

Zimniak, Andrzej. Jak nie zginie ludzkość. Solaris, 2008. 